\title{
Performance of different sources of organic manures in comparison with RDF and INM on nutrient uptake, nutrient balance and soil properties in rice-greengram cropping sequence
}

\author{
S. ALAGAPPAN* AND R.VENKITASWAMY \\ Department of Agronomy, Tamil Nadu Agricultural University, COIMBATORE (T.N.) INDIA \\ (Email : alga.s@rediffmail.com)
}

\begin{abstract}
Field experiments were carried out at Tamil Nadu Agricultural University, Coimbatore, India during samba (AugustDecember) season of 2012 and 2013 to study the effect of different sources of organic manures in comparison with INM and RDF on nutrient uptake and soil properties in rice (Oryza sativa L.). The experiment consisted of fourteen treatments which were laid out in Randomized Block Design, replicated thrice and SRI method of planting was adopted during both the years. Among fourteen treatments, four treatments with different organic manures at 100 per cent RDN on equi nutrient basis (farm yard manure, vermi-compost, poultry manure and (Dhaincha) green manure) another six treatments consisted of 50 per cent combination of each manure, one treatment with $1 / 4^{\text {th }}$ combination of all the manures and one absolute control (without organic or inorganic). These treatments were compared with the recommended dose of fertilizer (RDF) and integrated nutrient management practice (RDF + Dhaincha). Higher N, P and K uptake was observed with INM practice followed by RDF. Among the organic treatments, 100 per cent RDN through green manure resulted with higher nutrient uptake followed by 25 per cent RDN through each organic manures. Lower nutrient uptake was observed with absolute control where no fertilizers / manures received during both the years of study. The soil available $\mathrm{N}$ and $\mathrm{P}$ balance was positive with the INM treatment $\left(85.0\right.$ and $\left.5.10 \mathrm{~kg} \mathrm{ha}^{-1}\right)$ at the end of two year of cropping sequence. Among the organic treatments, 100 per cent RDN through green manure recorded the highest $\mathrm{N}$ balance (46.0 $\left.\mathrm{kg} \mathrm{ha}^{-1}\right)$ followed by 25 per cent RDN through each organic manures $\left(42.0 \mathrm{~kg} \mathrm{ha}^{-1}\right)$ at the end of the cropping system (2012 -14). Similarly, the highest $\mathrm{P}$ balance was recorded with 25 per cent RDN through each organic manures $\left(3.1 \mathrm{~kg} \mathrm{ha}^{-1}\right)$ and which was followed by 100 per cent RDN through green manure $\left(3.0 \mathrm{~kg} \mathrm{ha}^{-1}\right)$ at end of the two years of cropping sequence. The least $\mathrm{N}$ and $\mathrm{P}$ balance was noticed with absolute control (-4.0 and $\left.-2.5 \mathrm{~kg} \mathrm{ha}^{-1}\right)$ at the end of cropping sequence. Invariably, all the treatments recorded net negative $\mathrm{K}$ balance in both the years of cropping sequence.
\end{abstract}

Key Words : Rice- greengram cropping sequence, Organic manures, RDF, INM, Nutrient uptake, Nutrient balance, Soil properties

View Point Article : Alagappan, S. and Venkitaswamy, R. (2016). Performance of different sources of organic manures in comparison with RDF and INM on nutrient uptake, nutrient balance and soil properties in rice-greengram cropping sequence. Internat. J. agric. Sci., 12 (2) : 326334, DOI:10.15740/HAS/IJAS/12.2/326-334.

Article History : Received : 05.03.2016; Revised : 24.03.2016; Accepted : 20.05.2016

\footnotetext{
* Author for correspondence
} 